\title{
How Did Donald Trump Incite a Coup Attempt?
}

\author{
Christian Fuchs
}

University of Westminster, London, UK, http://fuchsc.net

Abstract: On 6 January 2021, supporters of Donald Trump after a Trump rally stormed the Capitol. This article asks: How Did Donald Trump incite a coup attempt? The presented research analyses parts of a dataset consisting of Trump's most recent 8,736 tweets as well as Trump's speech given at the rally that preceded the storming of the Capitol.

The article shows how Trump's speech and use of Twitter triggered violence and that the coup was the consequence of a long chain of events that unfolded as a consequence of Trump's authoritarian ideology, personality, and practices.

Keywords: Donald Trump, 6 January 2021, Capitol storming, Save America, right-wing authoritarianism, coup d'état

"Congress shall make no law respecting an establishment of religion [...] or abridging the freedom of speech, or of the press", says the US Constitution's First Amendment. The First Amendment does not protect speech that incites lawlessness that is imminent and likely, which includes the advocacy of crime and violence. How did Donald Trump incite the violence that erupted when his followers stormed the Capitol on January 6 ?

Between December 19 and January 6, Trump seven times announced the "Save America"-rally he held in Washington DC on the day his followers stormed the Capitol. In the first announcement, he tweeted, "Be there, will be wild!" (see figure 1). "To be wild" is a circumlocution for the use of violence. The call to attend the meeting went viral among Trump's followers on social media (Barry, McIntire and Rosenberg 2020). Far-right groups such as the Proud Boys, QAnon conspiracy theorists, The Oath Keepers, or Three Percenters joined (Hill 2021). Some Trump followers brought guns, Molotov cocktails, or pipe bombs (Porter 2021). 
Peter Navarro releases 36-page report alleging election fraud 'more than sufficient' to swing victory to Trump washex.am/3nwaBCe. A great report by Peter. Statistically impossible to have lost the 2020 Election. Big protest in D.C. on January 6th. Be there, will be wild!

\author{
10:42 PM - 18 Dec 2020
}

63,885 Retweets 211,432 Likes (2) (2) B (8)

๑ $30 \mathrm{~K} \uparrow 764 \mathrm{~K} \quad \bigcirc 211 \mathrm{~K}$

Figure 1: a tweet where Donald Trump announces the 6 January 2021-rally in Washington, D.C

In the two months between the day after the US presidential election and the coup attempt, the US President unleashed a constant stream of a total of 1,718 tweets, claiming the election was rigged and fraudulent. Using TAGS (Twitter Archiving Google Sheet) and Discovertext, the present author collected all Trump-tweets between June 22020 and January 82021 when Twitter shut down Trump's account, which resulted in a dataset consisting of 8,736 tweets. In these tweets, Trump constantly repeated the message that "they are trying to STEAL the Election. We will never let them do it" (4 November), until Twitter first temporarily and then permanently blocked his account. The block took effect after he had tweeted about the riots, "These are the things and events that happen when a sacred landslide election victory is so unceremoniously \& viciously stripped away from great patriots who have been badly \& unfairly treated for so long" (6 January). Conducting a word frequency analysis using NVivo showed that "ballot" (153), "fraud" (140 mentions), "fake" (77), and "rigged"l"rigging" (67) were among the most frequently utilised words in Trump's post-election tweets (see the resulting word cloud in figure 2). 


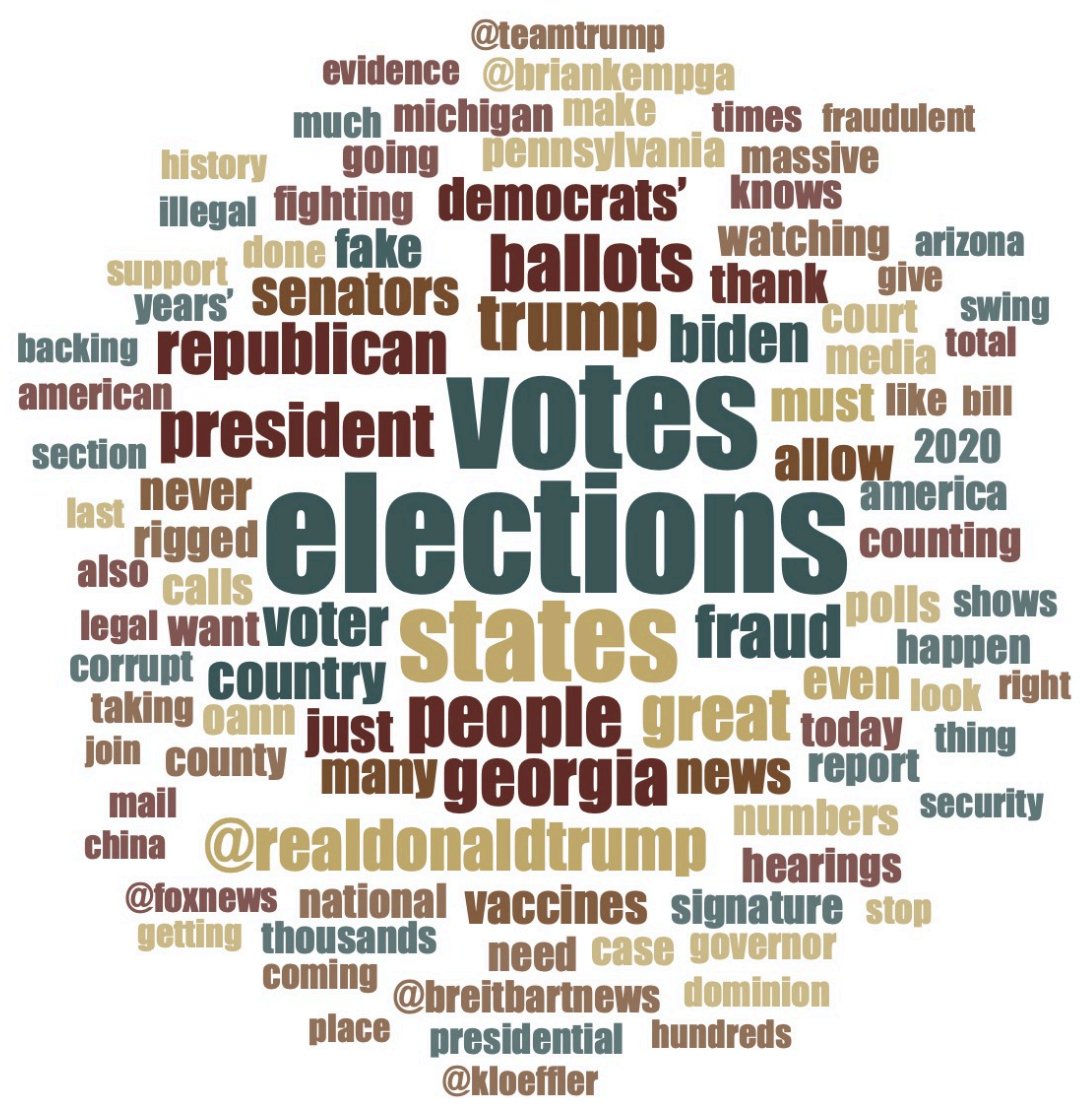

Figure 2: a word cloud of the text of all 1,718 tweets that Donald Trump posted between 4 January 2020 and 8 January 2021

Trump built up a high level of aggression among his followers step-by-step using social media, speeches, interviews, press conferences, etc. He is a highly mediated far-right politicians who cannot survive politically without having networked communication technologies at his disposal.

Trump's strategy to undermine the election results culminated in the events that unfolded on January 6. His 71-minute long speech at the "Save America"-rally triggered the coup attempt that followed (Trump 2021). What did Trump say in this speech?

Using NVivo, the present author analysed a transcript of Trump's speech. Besides references to the election, among the most frequently words (see the word cloud in figure 3) Trump used were "illegal"/"illegally" and "fight"/"fighting"/"fights". The main message the speech conveyed to the rally's attendants was that the election result was illegal and that therefore they had to fight. 


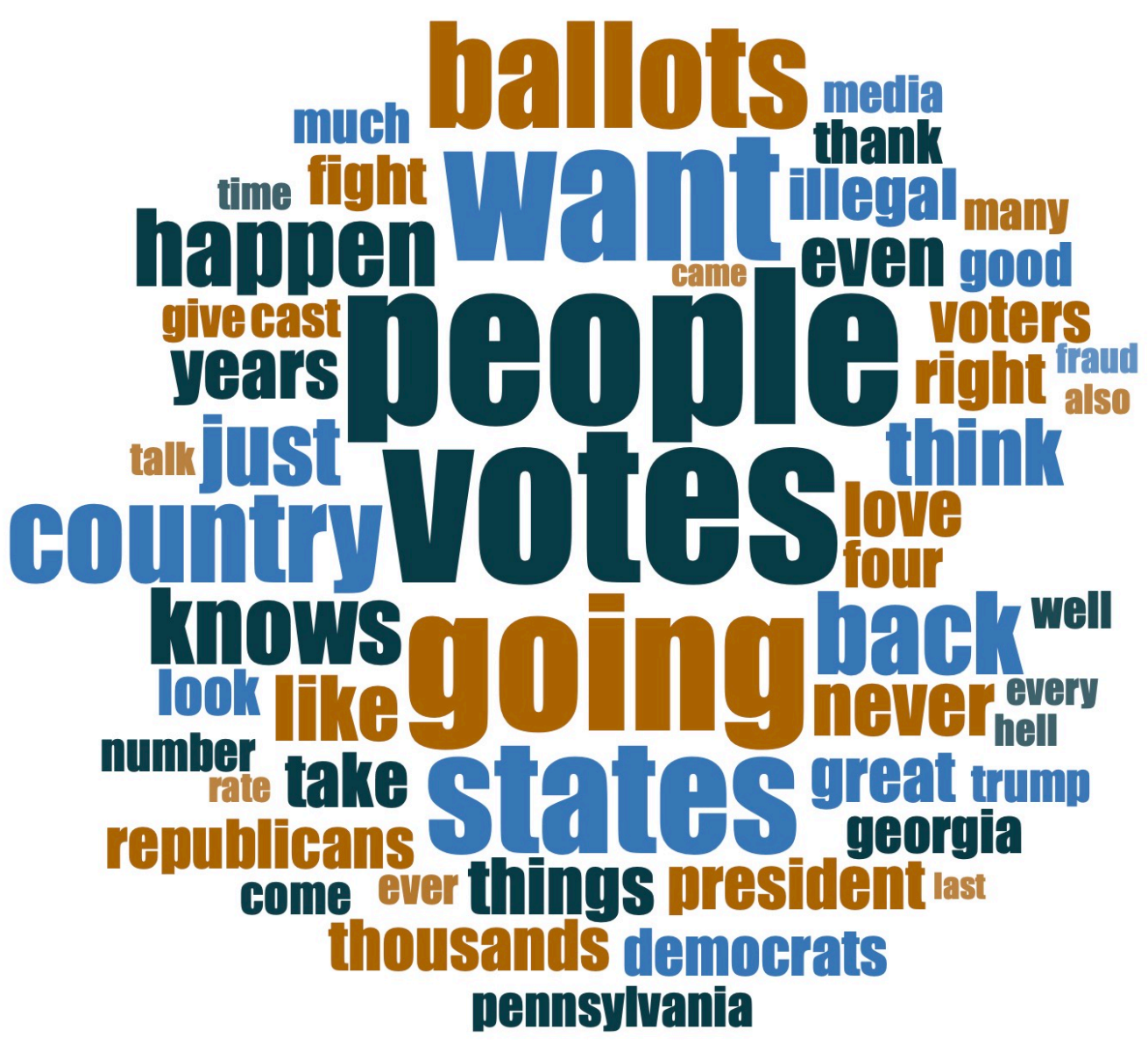

Figure 3: a word cloud of the transcript of Donald Trump's speech at the Save America-rally on 6 January 2021 in Washington, D.C.

Just like on Twitter, Trump also in this speech over and over repeated the false claim that the election was stolen from him and his followers:

"Hundreds of thousands of American patriots are committed to the honesty of our elections and the integrity of our glorious Republic. All of us here today do not want to see our election victory stolen by emboldened radical left Democrats, which is what they're doing and stolen by the fake news media" (Trump 2021).

"Our country has had enough. We will not take it anymore and that's what this is all about. To use a favourite term that all of you people really came up with, we will stop the steal" (Trump 2021).

Trump here uses what scholars such as Ruth Wodak in Critical Discourse Analysis call nationyms, words that refer to the nation (Reisigl and Wodak 2001, 50). In the Trumpspeech, example nationyms are "American patriots" and "our country". Trump combines the use of nationyms with the friend/enemy-scheme in order to construct a difference between "us" and his enemies who he claims have stolen the election and are the "radical left", the "Democrats", and "the fake news media".

Trump infers from his claims that something must be done, namely that his followers must act to "stop the steal". After the US election, \#stopthesteal has been a popular social media hashtag used by Trump followers. Trump himself used the hashtag 
seventeen times in his post-election tweets and thereby helped crafting and popularising it.

In his speech, Trump frequently described his opponents as "weak" and urged his followers to be "strong". For example, he spoke of "weak Republicans", "weak congresspeople" ("we got to get rid of the weak congresspeople"), or "the weak ones". Somatonyms are words or phrases that refer to features of the body (Reisigl and Wodak 2002, 48-49), such as bodily weakness or strength. Trump utilises somatonyms in order to construct a binary between strong friends and weak enemies.

The friend/enemy-scheme was popularised by fascist thinkers such as the Nazi legal scholar Carl Schmitt. He wrote that the concept of the enemies implies "to repel and fight them physically" (Schmitt 2007, 49). Extermination and war are the friend/enemy scheme's logical consequence. Following on from the use of the friend/enemyscheme and the strength/weakness binary, Trump referred in his speech no less than twenty times to "fight", "fights", and "fighting". In one instance, he imitated a boxer using his fists to symbolise how to fight. Here are some example usages from the analysed speech (Trump 2021):

- "you have to get your people to fight. If they don't fight, we have to primary the hell out of the ones that don't fight";

- "We're going to have to fight much harder";

- "And now we're out here fighting";

- "But it used to be that they'd argue with me, l'd fight. So l'd fight, they'd fight. I'd fight, they'd fight. Boop-boop";

- "And we fight. We fight like Hell and if you don't fight like Hell, you're not going to have a country anymore";

- "Together we are determined to defend and preserve government of the people, by the people and for the people".

By utilising the image of the fighter, Trump communicated to his followers that a battle had been going on that now reached its climax. The crowd responded to this image by chanting at the rally, on its way to and inside of the Capitol, "Fight for Trump! Fight for Trump! Fight for Trump!". Trump's lawyer Rudy Giuliani had earlier in a pre-speech called for "trial by combat", to which a Trump supported dressed in military gear reacted, "He just said, 'Trial by combat'. I'm ready! I'm ready!" (CNN 2021).

Starting from the false claim that the election was rigged and building up hatred against his identified enemies, Trump's speech culminated in calls that his followers should together with him march to the Capitol:

"After this, we're going to walk down and l'll be there with you. We're going to walk down. We're going to walk down any one you want, but I think right here. We're going walk down to the Capitol, and we're going to cheer on our brave senators, and congressmen and women. We're probably not going to be cheering so much for some of them because you'll never take back our country with weakness. You have to show strength, and you have to be strong" (Trump 2021).

Trump's fans followed this call and the result was the attempted coup. Although Trump once said that "everyone here will soon be marching over to the Capitol building to peacefully and patriotically make your voices heard", given his rhetoric at the speech, the repeated false claims that the election was rigged, and four year-long hate tirades against his enemies, it is no wonder that his followers forced entry into the Congress 
building, chanting slogans such as "Hang Mike Pence!" (Evon 2021) or screaming "Tell Pelosi we're coming for that bitch (TMZ 2021). Tell fucking Pelosi we're coming for her". Twitter stopped the Pence slogan when it trended (Pengelly 2021).

In previous research, the present author provided evidence that Donald Trump is a right-wing authoritarian who frequently utilises and practices top-down leadership, the friend/enemy-scheme, nationalism, law and order politics, and militarism (Fuchs 2018a, 2018b; Fuchs 2021, chapter 9). It was not a single speech by which Trump incited a coup. The speech at his rally was a trigger of a coup attempt that was incited by a long chain of events that unfolded as a consequence of Trump's authoritarian ideology, authoritarian personality, and authoritarian practices. Donald Trump's authoritarianism has made the world a more dangerous place, where the rise of new fascist societies has become an actual threat, and has brought the USA close to the brink of a civil war.

\section{References}

Barry, Dan, Mike Mclntire and Matthew Rosenberg. 2020. "Our President Wants Us Here": The Mob That Stormed the Capitol. New York Times, 9 January 2021, https://www.nytimes.com/2021/01/09/us/capitol-rioters.html

CNN. 2021. CNN Newsroom Transcript. CNN, 8 January 2021. http://edition.cnn.com/TRANSCRIPTS/2101/08/cnr.17.html

Evon, Dan. 2021. Was "Hang Mike Pence" Chanted at Capitol Riot? Snopes, 9 January 2021, https://www.snopes.com/fact-check/hang-mike-pence-chant-capitol-riot/

Fuchs, Christian. 2021. Social Media. A Critical Introduction. London: Sage. Third edition.

Fuchs, Christian. 2018a. Digital Demagogue: Authoritarian Capitalism in the Age of Trump and Twitter. London: Pluto.

Fuchs, Christian. 2018b. Authoritarian Capitalism, Authoritarian Movements and Authoritarian Communication. Media, Culture \& Society 40 (5): 779-791.

Hill, Becs. 2021. Active Far-Right Groups in the Capitol Riots. https://www.talkingaboutterrorism.com/post/active-far-right-groups-in-the-capitol-riots

Pengelly, Martin. 2021. "Hang Mike Pence": Twitter Stops Phase Trending After Capitol Riot. The Guardian, 10 January 2021, https://www.theguardian.com/us-news/2021/jan/10/hangmike-pence-twitter-stops-phrase-trending-capitol-breach

Porter, Tom. 2021. One of the Trump Supporters Who Stormed the US Capitol Was Carrying 11 Molotov Cocktails and an Assault Rifle, Prosecutors Say. Business Insider, 8 January 2021, https://www.businessinsider.com/trump-supporter-arrested-at-capitol-had-11-molotov-cocktails-feds-2021-1? $r=D E \& I R=T$

Reisigl, Martin and Ruth Wodak. 2001. Discourse and Discrimination. Rhetorics of Racism and Antisemitism. London: Routledge.

Schmitt, Carl. 2007. The Concept of the Political. Chicago, IL: The University of Chicago Press.

TMZ. 2021. Capitol Coup: Rioters Were Hunting For Pence, Pelosi ... Threats of Violence, Hanging. TMZ, 9 January 2021, https://www.tmz.com/2021/01/09/rioters-wanted-hurtnancy-pelosi-hang-mike-pence-capitol/

Trump, Donald. 2021. Transcript and video of the Trump-Speech at the Save America-Rally. 6 January 2021, https://www.rev.com/blog/transcripts/donald-trump-speech-save-americarally-transcript-january-6

\section{About the Author}

Christian Fuchs

Christian Fuchs is a critical theorist. He is the co-editor of tripleC: Communication, Capitalism \& Critique (http://www.triple-c.at). @fuchschristian http://fuchsc.net 